\title{
Transpiration and Stomatal Resistance Variations of Perennial Tropical Crops Under Soil water Availability Conditions and water Deficit
}

\author{
José Ozinaldo Alves de Sena ${ }^{1}$, Humberto Actis Zaidan ${ }^{2}$ and Paulo Roberto de Camargo e \\ Castro $^{3}$ \\ ${ }^{I}$ Departamento de Agronomia; Universidade Estadual de Maringá; Av. Colombo, 5.790; 87.020-900; \\ joasena@uem.br; Maringá - PR - Brasil. ${ }^{2}$ Curso de Pós-Graduação da UNESP/Jaboticabal; Doutorado em \\ Genética e Melhoramento de Plantas. ${ }^{3}$ Departamento de Ciências Biológicas; ESALQ/USP; C. P. 9; 13418-900; \\ Piracicaba - SP - Brasil
}

\begin{abstract}
During the dry and rainy seasons, determinations of stomatal resistance and transpiration of five tropical crops were carried out: guarana (Paullinia cupana Kunth), coffee (Coffea arabica L.), cashew (Anacardium occidentale L.), guava (Psidium guajava L.) and rubber (Hevea brasiliensis Muell. - Arg.) trees. Experimental design was done at randomized complete blocks with five replications. During the dry season there was a decrease in values of stomatal resistance in the following order: guarana > coffee > cashew> guava > rubber, with values from 2.5 to

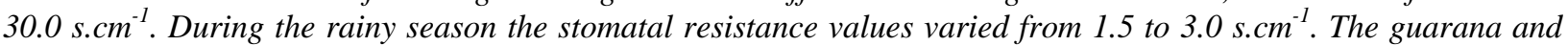
coffee crops showed higher resistance to water transpiration when compared to other crops. During the rainy season, the rubber tree continued to present lower stomatal resistance and, consequently, higher transpiration.
\end{abstract}

Key words: Trees, water relations, tropical crops

\section{INTRODUCTION}

Water deficit has been considered as the most important factor, limiting the carbon absorption, growth and consequently, the primary liquid production in plants. When the water is in low supply, the water loss by transpiration may exceed the water absorbed by the roots during the day or season, especially for plants with great canopy and/or restricted stomatal control (Dawson, 1993). When the demand exceeds the supply, perennial plants can regulate the water use found in additional water sources or find other ways to conserve water for both metabolism and growth needs. There is a great variety of morphological, anatomical and physiological characteristics that either look for adaptation or act as a buffer against the negative water deficit effects. In water deficit conditions, the water vapor loss occurs through two parallel ways, the stomatal and the cuticular, being the stomatal participation more significant in the transpiration loss mechanism than cuticular (Larcher, 1980). When the water supply is reduced, the stomatal guard cells lose solutes, increasing their water potential, thus, causing reduction of their pressure potential and subsequent stomatal closure (Awad and Castro, 1992). In plants with adequate water supply, the stomatal opening reduces drastically the water exit resistance from the inner of the leaves towards the

\footnotetext{
${ }^{*}$ Author for correspondence
} 
atmosphere. In these conditions when the guard cells receive solar energy there will be fixation of $\mathrm{CO}_{2}$, with a consequent reduction of $\mathrm{CO}_{2}$ concentration in the inner of the cells resulting in $\mathrm{H}^{+}$active excretion and quick $\mathrm{K}^{+}$absorption and subsequently, stomatal opening. The abscisic acid (ABA) can inhibits the $\mathrm{H}^{+}$extrusion which inhibits the $\mathrm{K}^{+}$absorption, reduction of pressure potential, reduction of the guard cells's slowness, resulting in stomatal closure (Hartung, 1983; Castro et al., 2002). The amount of this substance in both mono and dicotyledoneous leaves increase substantially when the leaves go through water stress (Salisbury and Ross, 1992), either in detached leaves or attached ones. It has also been verified that the increase of $\mathrm{ABA}$ concentration causes stomatal closure in various species, causing them to keep closed in the light as well as in the dark for many days. Plant roots taken to water stress can also form $\mathrm{ABA}$, which is transported by the xylem to the leaves causing stomatal closure as a mechanism of protection against dryness.

The stomatal transpiration and resistance levels may vary daily or seasonally according to the species or plant variety. Higher levels of stomatal conductance can be observed in the morning in hot seasons of tropical regions, if compared to other periods of the day (Harding et al., 1992; Roberts and Rosier, 1993). The stomatal conductance declining during the year can be negatively correlated to the soil water deficit. In tropical conditions, it is predictable that reduced stomatal conductance periods (high stomatal resistance) may be related to a residual cuticular conductance (cuticular transpiration), low water potential of cells and stomatal closure (Roberts and Rosier, 1993). The less negative cell water potentials may represent greater water availability or a better plant ability to retain water for certain plant species. Transpiration may also vary according to solar radiation; as a strategy to keep the photosynthesis levels meeting the system's biochemical demands (Larcher, 1980; Yang et al., 1990), in high light intensity and high temperature, some species show lower leaf temperature than the environmental temperature. Comparing native and introduced $\mathrm{C} 4$ grasses, Baruch and Fernández (1993), verified that Hyparrhenia rufa an invasive species, presented higher stomatal conductance, transpiration, leaf water and osmotic potential than the native one, putting in evidence the lower tolerance of the invasive plant to stress conditions. Higher levels of stomatal resistance for the field peanut crops were observed in hotter periods than in the mild ones (Hirose et al., 1994). In Central Amazon, Piedade et al. (1994), observed that Echinochloa polystachya, a C4 grass, had a 50\% decrease on stomatal conductance in the dry period and a $35 \%$ depression on the relation to $\mathrm{CO}_{2}$ leaf external concentration / $\mathrm{CO}_{2}$ intercellular concentration, when compared to regular water availability. Santrucek (1991) also studied C3 and $\mathrm{C} 4$ species for its good water economy. $\mathrm{He}$ verified that the $\mathrm{C} 4$ plants studied showed better transpiration efficiency with the increase of air relative humidity than the $\mathrm{C} 3$ ones (Nicotiana tabacum and Datura stramonium).

The stomata are decisive regulators of the diffusion processes. The variation in the stomatal pore opening will simultaneously lead to the $\mathrm{CO}_{2}$ entrance control to the leaf and water vapor release. The stomata resistance to diffusion increases greatly with the reduction of the pore opening (Larcher, 1980). The opening capacity is greater in dicotyledonous herbal leaves, in deciduous leaf trees and tropical forest trees. However it is low in plants with thick and hard leaves. Chartzoulakis et al. (1992), studying water deficit in kiwifruit crop, verified that water stress reduced the photosynthesis level from $53 \%$ to 64 $\%$ in relation to plants with adequate water supply. That decline was due to the stomatal closure. In this same study the relation root/aerial part of less stressed plants was 3.5 bigger than in plants with water deficit, showing that water stress in kiwifruit alter the dry matter distribution pattern, favoring the roots. On another hand, significant differences of stomatal conductance were not verified for the Maranthes corymbora species in the morning and evening (Eamus et al., 1993).

Growth and performance reduction by water stress has been very well documented (Fischer, 1980; Kriedemann and Barrs, 1981), although different physiological processes have been proposed to explain these reductions. Initially, the stress may cause loss of cellular hardening (Hsiao et al., 1976), concurring to reduce gas changes and the leaf lengthening. Both are hardening process dependent (Bradford and Hsiao, 1982). The result is a decrease in growth levels, since this factor is a function of photosynthesis and of leaf area (Chartzoulakis et al. 1992).

Despite of the higher level of potential photosynthesis under optimal conditions in relation to $\mathrm{C} 3$ plants, the $\mathrm{C} 4$ species are more abundant in semi-arid tropics and sub-tropics, 
where its occurrence has been attributed to its high efficiency in using water than to its high photosynthetic potential (Jones et al., 1992). After studying Prunus cerasoides, Celtis australis and Grewia oppositifolia plants, Bhatt (1990) verified that light potential absorption was identical for the three species, presenting $P$. cerasoides and $C$. australis, respectively, the maximum and the minimum transpiration level. The transpiration level was positively correlated to the conductance for water vapor of the adjacent air layer to the leaf.

\section{MATERIAL AND METHODS}

The experiment was carried out at Crop Production Department of Escola Superior de Agricultura "Luiz de Queiroz", Piracicaba, São Paulo. Adult plants were used of following species: guarana (Paullinia cupana Kunth) (GR), coffee (Coffea arabica L.) (CF), cashew (Anacardium occidentale L.) (CJ), guava (Psidium guajava $\mathrm{L}$.) (GO) and rubber (Hevea brasiliensis Muell. - Arg.) (SER). During the dry (September/94) and the rainy (November/94) seasons, determinations of stomatal resistance (s. $\left.\mathrm{cm}^{-1}\right)$ and transpiration $\left(\mu \mathrm{g} . \mathrm{cm}^{-1} \cdot \mathrm{s}^{-1}\right)$ were carried out with the different species. The environmental average temperature in the dry season during the evaluation period was $32.7{ }^{\circ} \mathrm{C} \pm 1.04$, and $35.9{ }^{\circ} \mathrm{C}$ \pm 1.41 in the rainy season. The evaluations were performed with a Li-Cor 1600 porometer, from 10 a.m to 2:00 p.m. in a low foggy day, using adults leaves from the medium third of plants in branches exposed to light. Experimental design was done as randomized complete blocks with five replications and the data was submitted for variance analyses and average comparative test (Tukey $5 \%$ ).

\section{RESULTS AND DISCUSSION}

Significant differences for transpiration and stomatal resistance values were observed among species, especially during water deficit period (Figs. 1 and 2). During this period, the transpiration values varied from 2.0 to $17.0 \mu \mathrm{g} . \mathrm{cm}^{-}$ ${ }^{1} . \mathrm{s}^{-1}$ and the stomatal resistance from 2.5 to 30.0 $\mathrm{s} . \mathrm{cm}^{-1}$, for the different species, presenting crescent transpiration values and decreasing stomatal resistance in the following order: guarana tree $>$ coffee $>$ cashew $>$ guava $>$ rubber. On the other hand, it was less evident during rainy season for both variables, being the rubber crop the one to present smaller stomatal resistance and greater transpiration. This period's transpiration values varied from 13.0 to $23.0 \mu \mu \mathrm{g} . \mathrm{cm}^{-1} . \mathrm{s}^{-1}$ and stomatal resistance ones from 1.5 to $3.0 \mathrm{s.cm}^{-1}$, being observed the following tendency in crescent order: 1. transpiration: rubber $>$ cashew $>$ guava $>$ guarana $>$ coffee (Fig. 1); 2. stomatal resistance: guarana tree $>$ coffee $>$ cashew $>$ guava $>$ rubber (Fig. 2).

Independenty of the evaluation period, the species could be divided into two distinct groups; Group 1 (coffee and guaraná) and Group 2 (rubber, guava and cashew), since they presented statistically different behavior for the analyzed variables (Tables 1 and 2). However, during the water deficit period the differences among the species groups became greater, in relation to rainy evaluation periods (Fig. 3). Because of guarana and coffee crops presented greater stomatal resistance in relation to the remaining cultures, especially in the dry period, it coluld be presumed the acting of physiological mechanisms for these species under water stress conditions, resisting to water loss and resulting in better adaptation to drought for more superficial root system species. In these conditions it is expected that the partial stomatal closure, with the objective of restraining the water vapor loss and minimizing the energy loss by transpiration, may also restrain the $\mathrm{CO}_{2}$ entrance, resulting water economy and reduction of defoliation.

The remaining cultures, mainly the ones more adapted to dry weather and high temperatures, cashew, guava and rubber, probably have physiological mechanisms as more efficient or and deep root systems that permit to be more tolerant even thought less resistant to water loss or in partial stomatal closure conditions and to use and extract more efficiently the water available in the soil. Thus, a higher tolerance of these species to water deficit conditions and high temperatures, especially during summer in tropical regions, could be expected. 


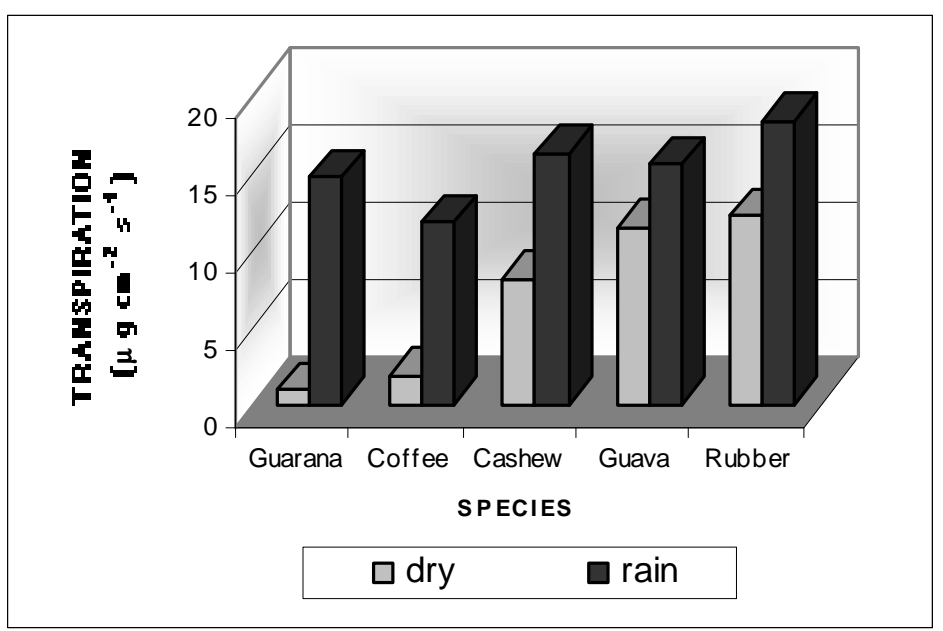

Figure 1 - Transpiration for the studied tropical species during the dry and rainy seasons. Average of 5 replications.

$\underline{\text { Table } 1 \text { - Transpiration average }\left(\mu \mathrm{g} . \mathrm{cm}^{-2} \cdot \mathrm{s}^{-1}\right) \text { among species and Tukey test. }}$

\begin{tabular}{cc}
\hline SPECIES & MEANS ${ }^{1}$ \\
\hline Rubber tree & $15.11 \mathrm{a}$ \\
Gava tree & $13.48 \mathrm{a}$ \\
Cashew tree & $11.60 \mathrm{a}$ \\
Coffee tree & $4.85 \mathrm{~b}$ \\
Guarana tree & $3.80 \mathrm{~b}$ \\
\hline${ }^{1}$ Transformed data $(\log \mathrm{x})$. Means followed by distinct letters differ among themselves by the Tukey test at $5 \%$ level. V.C $=11.5 \%$
\end{tabular}

${ }^{1}$ Transformed data $(\log \mathrm{x})$. Means followed by distinct letters differ among themselves by the Tukey test at $5 \%$ level. V.C $=11.5 \%$

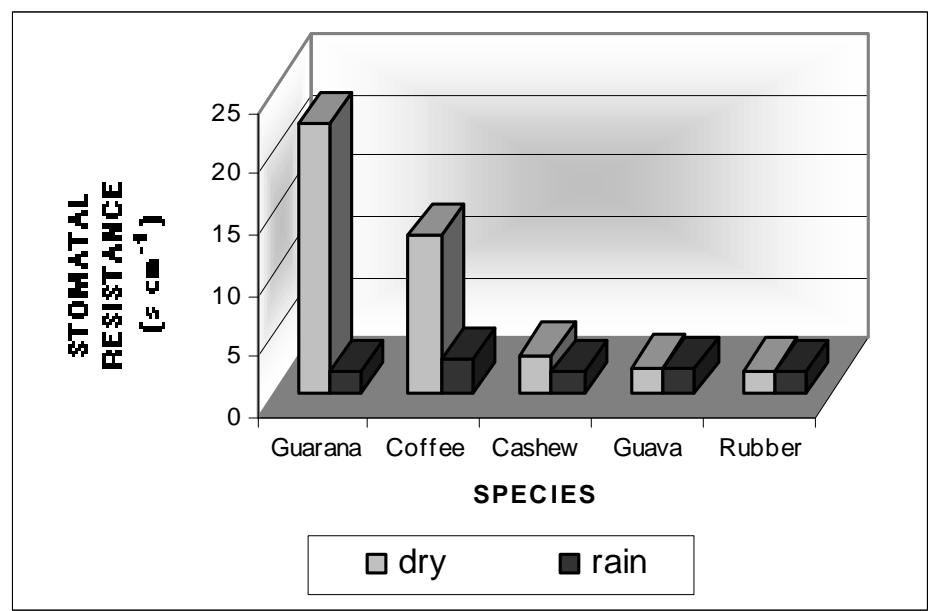

Figure 2 - Stomatal resistance for the studied tropical species during the dry and rainy seasons. Average of 5 replications. 


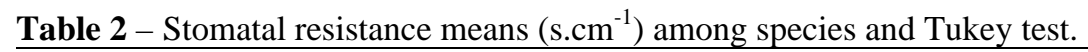

\begin{tabular}{cc}
\hline SPECIES & MEANS ${ }^{1}$ \\
\hline Guarana tree & $6.46 \mathrm{a}$ \\
Coffee tree & $6.13 \mathrm{a}$ \\
Cashew nut tree & $2.40 \mathrm{~b}$ \\
Guava tree & $2.16 \mathrm{~b}$ \\
Rubber tree & $1.85 \mathrm{~b}$ \\
\hline${ }^{1}$ Transformed data $(\log x)$. Means followed by distinct letters differ among themselves by the Tukey test at $5 \%$ level. V.C $=23.0 \%$
\end{tabular}
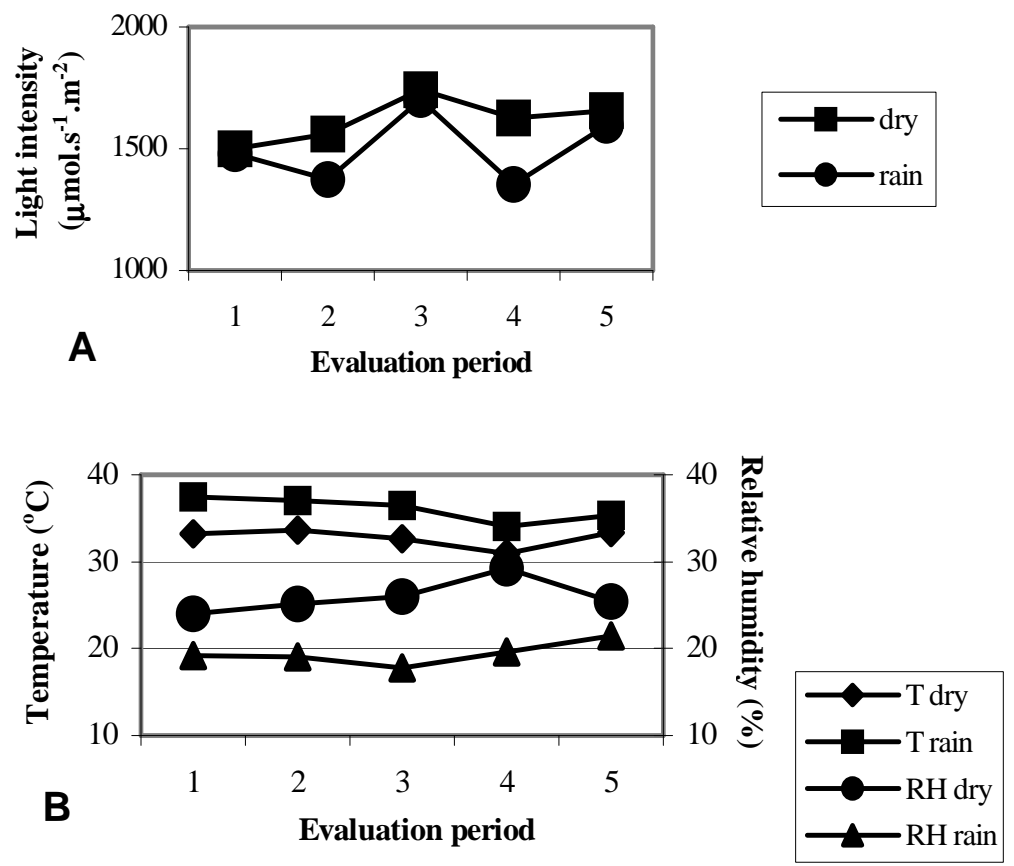

Figure 3 - Light intensity (A), temperature and average relative humidity (B) during the dry and rainy evaluation periods. Mean of 5 replications

\section{CONCLUSIONS}

Under water suppression conditions, cashew, guava and rubber species were less resistant to water loss, but they were more tolerant probably by other mechanisms as depth of root systems. It was probable that because of high stomatal resistance and low transpiration the coffee and guarana were less tolerant to soil water deficit but more resistant to water loss.

\section{RESUMO}

O experimento foi realizado no Departamento de Produção Vegetal da Escola Superior de Agricultura "Luiz de Queiroz", ESALQ/USP, Piracicaba, São Paulo, Brasil, utilizando-se as culturas de guaranazeiro (Paullinia cupana Kunth), cafeeiro (Coffea arabica L.), cajueiro (Anacardium occidentale L.), goiabeira (Psidium guajava L.) e seringueira (Hevea brasiliensis Muell. - Arg.). No período de seca (setembro/94) e de chuvas (novembro/94), realizaram-se determinações de resistência estomática (RE) (s $\left.\mathrm{cm}^{-1}\right)$ e transpiração $(\mathrm{T})\left(\mu \mathrm{g} \mathrm{cm} \mathrm{s}^{-1}\right)$ nas diferentes 
espécies. $\mathrm{O}$ delineamento experimental foi em blocos casualizados com cinco repetições. A partir das análises dos dados pode-se concluir: 1 . diferenças significativas entre espécies, em termos das variáveis avaliadas no período de deficiência hídrica, com valores decrescentes de resistência estomática e crescente de transpiração na seguinte ordem: guaranazeiro > cafeeiro > cajueiro > goiabeira > seringueira; 2. Nas águas as diferenças entre espécies, para ambas as variáveis, foram menos evidentes, continuando a cultura da seringueira a apresentar menor resistência estomática e maior transpiração dentre as espécies; 3. As culturas de guaraná e café apresentaram maior resistência à perda de água, em relação às demais culturas.

\section{REFERENCES}

Awad, M. and Castro, P. R. C. (1992), Introdução à fisiologia vegetal, Nobel, São Paulo.

Baruk, Z. and Fernandez, D.S.(1993), Water relations of native and introduced $\mathrm{C} 4$ grasses in a neotropical savanna. Oecologia, 96, 179-185.

Bhatt, R.K.(1990), Seasonal variation in light absorption and transpiration in Prunus, Celtis and Grewia. Indian Journal of Forestry, 13, 118-121.

Bradford, K.J. and Hsiao, T.C. (1982), Physiological responses to moderate water stress. In- Physiological plant ecology - Water relations and carbon assimilation, eds. O. Lange; P. S. Nobel; C. B. Osmond; H. Zeigler. Encyclopedia of Plant Physiology. Springer, v. 12B., pp. 263-324.

Castro, P.R.C.; Sena, J.O.A. and Kluge, R.A. (2002), Introdução à fisiologia do desenvolvimento vegetal, Eduem, Maringá.

Chartzoulakis, K.; Noitsakis, B. and Therios, I. (1992), Photosynthesis, plant growth and dry matter distribution in kiwifruit as influenced by water deficits. Irrigation Science, 14, 1-5.

Dawson, T.E. (1993), Hydraulic lift and water use by plants: implications for water balance, performance and plant-plant interactions. Oecologia, 95, 565-574.

Eamus, D.; Berryman, C.A. and Duff, G.A. (1993), Assimilation, stomatal conductance, specific leaf area and chlorophyll responses to elevated $\mathrm{CO}_{2}$ of Maranthes corymbosa, a tropical monsoon rain forest specie. Aust. J. Plant Physiology, 20, 741-755.

Fischer, R.A. (1980), Influence of water stress on crop yield in semi arid regions. In- Adaptation of plants to water and high temperature stress, eds. T. C. Turner; P. Kramer. Willey and Son, New York, pp. 323-340.
Harding, R.J.; Hall, R.L.; Swaminath, M.H. and Srinivasa Murthy, K.V. (1992), The soil moisture regimes beneath forest and agricultural crop in southern India - measurements and modeling. InGrowth and water use of forest plantations, eds. I. R. Calder; R. L. Hall; P. G. Adlard. John Wiley, Chichester, pp. 244-269.

Hartung, W. (1983), The site of action of abscisic acid at the guard cell plasmalemma of Valerianella locusta. Plant Cell Environ., 16, 427-428.

Hirose, T.; Ikeda, M. and Izuta, T. (1994), Stomatal oscilation in peanut leaves observed under field conditions. Japan. J. Crop Sci., 63(1), 162-163.

Hsiao, T.C.; Acevedo, E.; Fereres, E. and Henderson, D.W. (1976), Stress metabolism: water stress, growth and osmotic adjustment. Phil. Trans. R. Soc. Lon., 273, 479-500.

Jones, M.B.; Long, S.P. and Roberts, M.J. (1992), Synthesis and conclusions. In- Primary productivity of grass ecosystems of the tropics and subtropics, eds. S. P. Long; M. B. Jones; M. J. Roberts. Chapman and Hall, London, pp. 212-255.

Kriedemann, P.E. and Barrs, H.D. (1981), Citrus orchards. In- Water deficit and plant growth, ed. T. T. Kozlowski. Academic Press, New York, pp. 325-417.

Larcher, W. (1980), Physiological plant ecology. Springer-Verlag, Berlin.

Piedade, M.T.F.; Long, S.P. and Junk, W.J. (1994), Leaf and canopy photosynthetic $\mathrm{CO} 2$ uptake of a stand of Echinocloa polystachya on the central Amazon floodplain. Are the high potential rates associated with the $\mathrm{C} 4$ syndrome realized under the near-optimal conditions provided by this exceptional natural habitat? Oecologia, 97, 193-201

Roberts, J. and Rosier, P.T.W. (1992), Physiological studies in young Eucalyptus stands in southern India and derived estimates of forest transpiration. Agricultural Water Management, 24, 103-118

Salisbury, F.B. and Ross, C. (1992), Plant Physiology. Wadsworth Publishing, Belmont, California.

Santrucek, J. (1991), Transpiration efficiency and apparent cuticular transpiration in some C3 and C4 plants. Biologia Plantarum, 33(3), 192-199

Yang, X.; Short, T.H.; Fox, R.D. and Bauerle, W.L. (1990), Transpiration, leaf temperature and stomatal resistance of a greenhouse cucumber crop. Agricultural and Forest Meteorology, 51(3-4), 197209

Received: December 13, 2004; Revised: October 03, 2005; Accepted: December 20, 2006. 